\title{
The glacial impact on an exhumed sub-Mesozoic etch surface in southwestern Sweden
}

\author{
Mats Olvmo, ${ }^{1}$ Karna Lidmar-Bergström, ${ }^{2}$ Göran Lindberg ${ }^{2}$ \\ ${ }^{1}$ Department of Geosciences, P.O. Box 460, Göteborg University, S-41381 Göteborg, Sweden \\ ${ }^{2}$ Department of Physical Geography, University of Stockholm, S-10691 Stockholm, Sweden
}

\begin{abstract}
Along the northern part of the western coast of Sweden, the landscape is characterized by joint-aligned valleys with intervening rock hills. Precambrian bedrock is exposed over large areas and the Quaternary cover is mainly restricted to the bottom of narrow valleys. The well-exposed bedrock exhibits many glacial forms, but recently the major landforms have been interpreted as exhumed sub-Mesozoic etch forms. To gain insight into the relative roles of different processes in shaping the present forms, we studied a granite area where the rock hills contain fractures and narrow clefts with weathering forms and saprolite remnants. Marks of glacial erosion are found only in the upper parts of the clefts, where erosion by subglacial meltwater has exploited weathered preglacial sheeting structures to form furrows with concave cross profiles ( $p$ forms). On the summit surfaces, glacial erosion has been of greater importance, but the roche moutonnées found here are also structurally controlled. The main impact of glacial erosion is plucking on the order of tens of metres. Thus, landscapes labelled "areally scoured glacial terrain" can, at some locations, also be described as stripped and slightly incised etch surfaces.
\end{abstract}

\section{INTRODUCTION}

It is often taken for granted that glacial erosion was the main land-forming agent in formerly glaciated areas. However, in some cases when the large-scale forms of the bedrock are examined, it is impossible to see any patterns that relate to glacial-flow patterns, with the exception of some great lakes, fjords and lake basins along mountain fronts. If the landform categories are examined, with respect to saprolite remnants and cover rocks, another picture can emerge (LidmarBergström, 1995a, b). Wherever the Precambrian basement emerges from below lower Paleozoic cover rocks on the Baltic and Canadian Shields, it is extremely flat. On the other hand, where it emerges from below Jurassic and Cretaceous cover rocks, it is hilly with a relative relief up to more than $200 \mathrm{~m}$. Remnants of deep ( $<60 \mathrm{~m}$ thick) kaolinitic saprolites are abundant in close connection with the covers in southern Sweden. The relief is etched out along fractures and other zones easily affected by deep weathering; a structural and lithological control is obvious in these areas, which are labelled exhumed sub-Mesozoic etch surfaces (LidmarBergström, 1988, 1989). A third type of relief exists, plains with residual hills which, as far as we know, have not been protected by any cover rocks or may have had a short-lived Eocene cover at certain elevations. The development of these three types of topographies seems to be related to uplift and exposure during specific Phanerozoic periods, interrupted by long intervals with subsidence and covering of the forms in the basement. The present distribution seems to be the result of Tertiary uplift events (Lidmar-Bergström, 1999).

In southeastern Sweden, an exhumed sub-Cambrian surface rises gently from near sea level, close to the coast, to $300 \mathrm{~m}$ a.s.l., $75 \mathrm{~km}$ inland, with a relative relief below $20 \mathrm{~m}$ within the intact parts. The exhumed sub-Cambrian peneplain also occupies large parts of central Sweden. It is more or less faulted (Lidmar-Bergström, 1996; fig. 13) and some areas can therefore have moderate relief; but within the fault blocks, flat relief is maintained. The vertical throws are mainly only tens of metres, but can be up to $150 \mathrm{~m}$. Glacial erosion has not obliterated these exhumed fault-line scarps. The sub-Cambrian peneplain occupies the Väner Basin (Fig. 1). In its southern parts, remnants of lower Paleozoic cover rocks are preserved as mesas and buttes below capping dolerite. The peneplain rises to the south and west. It is probably never very far from the summit surfaces, even along the west coast, as Cambrian fissure-fillings are present (Samuelsson, 1975). The relief changes dramatically towards the coast, from a well-preserved featureless plain to a structurally and lithologically controlled landscape that disappears below Jurassic/lower-Cretaceous cover rocks in the Skagerrak. By its general relation to Mesozoic cover rocks, reports of kaolinized fractured zones and the type of relief similar to the well-dated exhumed sub-Cretaceous relief in southeastern Sweden (Lidmar-Bergström, 1988, 1989, 1995b; Elvhage and Lidmar-Bergström, 1987; Lidmar-Bergström and others, 1999), this higher-relief landscape is interpreted as an exhumed sub-Mesozoic etch surface. The total amount of erosion in southern Sweden, in basement areas with exhumed sub-Mesozoic relief, since the re-exposure of the subCambrian peneplain in the Mesozoic, ranges from zero on some hill tops (later exhumation?) to about $200 \mathrm{~m}$ (LidmarBergström, 1988, 1997). The erosion includes stripping of saprolites that may have been several tens of metres thick or more. The erosion occurred during three distinct intervals: before the sedimentation of the cover rocks, after a second re-exposure in the Late Tertiary and by glacial erosion during the Quaternary. How much of the Cretaceous cover was already gone in the Late Tertiary is difficult to judge, but 


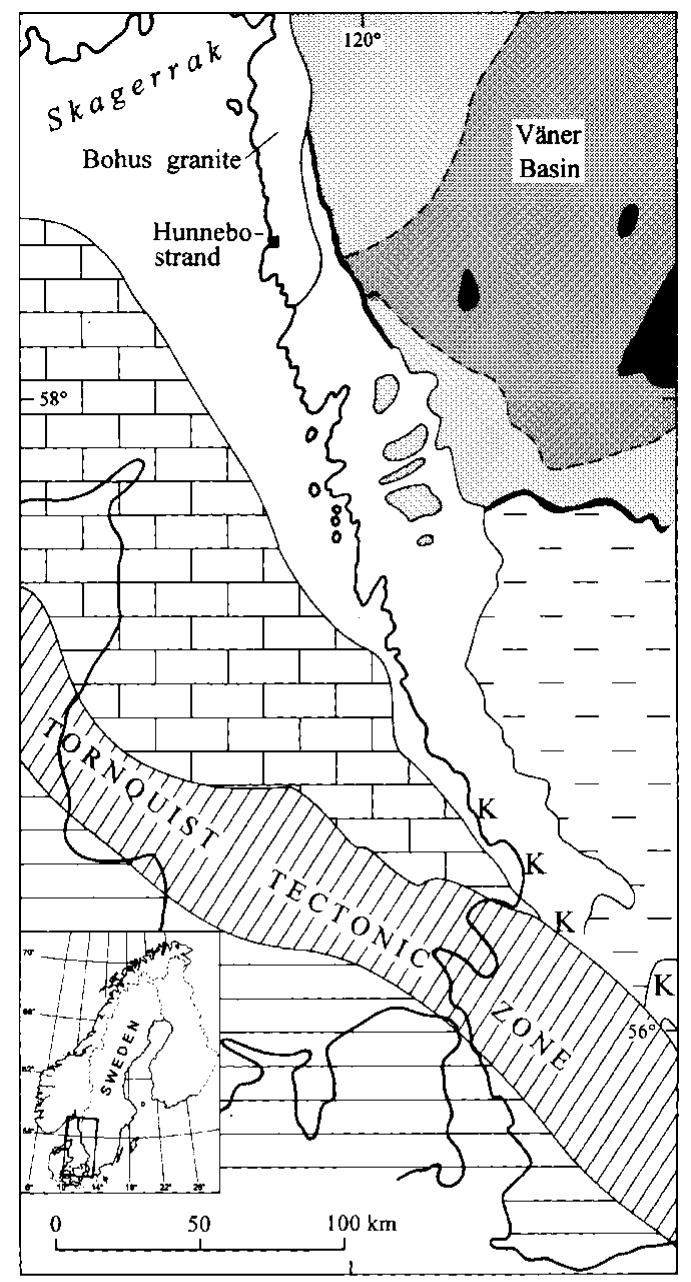

Relief in basement

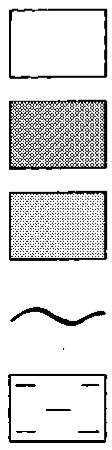

sub-Mesozoic etch surfaces

sub-Cambrian peneplain (intact)

sub-Cambrian peneplain (dissected)

uplifted rim of sub-Cambrian $p$

Cover rocks

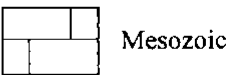

K $\begin{aligned} & \text { Cretaceous } \\ & \text { outliers }\end{aligned}$

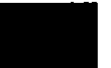

ower

Palaeozoic

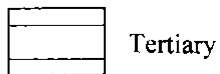

\section{South Småland} Tertiary surface

Fig. 1. Map of palaeosurfaces in southern Sweden with the study area indicated.

exhumed sub-Cretaceous relief in southern Sweden, with weathered flints as the only remnant of the former Cretaceous cover (Lidmar-Bergström, 1982) and the occurrence of short transported silicified wood probably of Miocene age (Kornfält and Bergström, 1983), suggest erosion of the cover rocks here before the glaciations. A Late-Tertiary erosion of the covers along the northern part of the west coast is suggested due to the total loss of the Cretaceous cover here, despite the irregular topography, as well as the long distance to preserved cover rocks in the Skagerrak (Fig. 1).

Bohus granite occupies the northern part of the Swedish west coast. The bedrock is exposed over large areas, which has given opportunities for detailed studies of glacial forms (Ljungner, 1930; Johnson, 1956) and, according to common text books, the landscape must be labelled "an areally scoured glacial terrain" (cf. Sugden and John, 1976; Sugden,
1978; Menzies, 1996). However, the recognition of its character, mainly as an exhumed etch surface (Lidmar-Bergström, 1995b), gave rise to the question: what, in reality, is the glacial impact on the forms? If the bedrock surfaces are examined in detail in the field, is it then possible to judge which processes have been involved in the ultimate shaping of the forms and the relative importance of the processes involved?

The occurrence of a kaolinized fracture zone (LidmarBergström and others, 1999) and the existence of large clefts with weathered walls within a rock hill at Hunnebostrand, Bohuslän (Fig. 1), made this area suitable for a detailed study. The purpose was to examine meso- and micro- forms in the field to ascertain what processes and structures were responsible for the relief, and to get a perspective on the effect of glacial erosion on the exhumed sub-Mesozoic granite surface. For interpretations of glacial geomorphology, it is important to be able to ascertain what is glacial and what is non-glacial relief.

\section{GEOLOGY AND TOPOGRAPHY}

In the northernmost part of the Swedish west coast, the bedrock is predominately $920 \mathrm{Myr}$ old Bohus granite (Lundqvist and Bygghammar, 1994). Several textural and colour varieties occur, but the dominant type is greyish-red, medium-grained and massive (Asklund, 1947). The bedrock relief is characterized by sets of straight valleys, lake basins and other depressions, interrupted by well-defined square-, lozenge- or irregularly shaped rock hills forming steep-sloped plateaux or domes. The straight outline of the landscape expresses structural contrasts within the basement rocks, revealed by exogenic processes. The relief amplitude is normally between 20 and $100 \mathrm{~m}$, however, in some extreme cases it is close to $150 \mathrm{~m}$ and even $200 \mathrm{~m}$ from the fresh bedrock in a fjord bottom to the nearby hilltops (Flodén, 1973; p. 98). The hills mainly lack cover of Quaternary deposits and bedrock is exposed. The small- to medium-sized bedrock forms are characterized by massive glacial scouring from the northeast, and roche moutonnées are the dominant medium-scale landforms. Large valleys are frequently flat-floored, due to thick infill of glaciomarine clays deposited during the late Weichselian deglaciation (about 13000-12400 BP). The highest late-glacial shoreline ranges from $110 \mathrm{ma.s.l}$. in southern Bohuslän to above $170 \mathrm{~m}$ a.s.l. in the north (Lundqvist, 1994).

\section{STUDY AREA}

Hunnebo is situated within the Bohus granite on the Sotenäs peninsula (Fig. 1). Three sets of fractures north-south, northeast-southwest and west-northwest-east-southeast have been mapped from air photos (Fig. 2). Valleys have developed along these fractures and, between the clay-filled valleys, rock hills with exposed bedrock occur. There are several isolated hills in the area, and south of Hunnebostrand, two larger circular, steep-sided, plateau-crested granite hills rise to about $65 \mathrm{~m}$ above the adjacent sea level (Fig. 2). The round shapes of the hills is a result of the fracture patterns. The northern hill (Fig. 3, inset map) has a system of joints in the west, where large clefts have developed. This part was chosen for detailed study. 

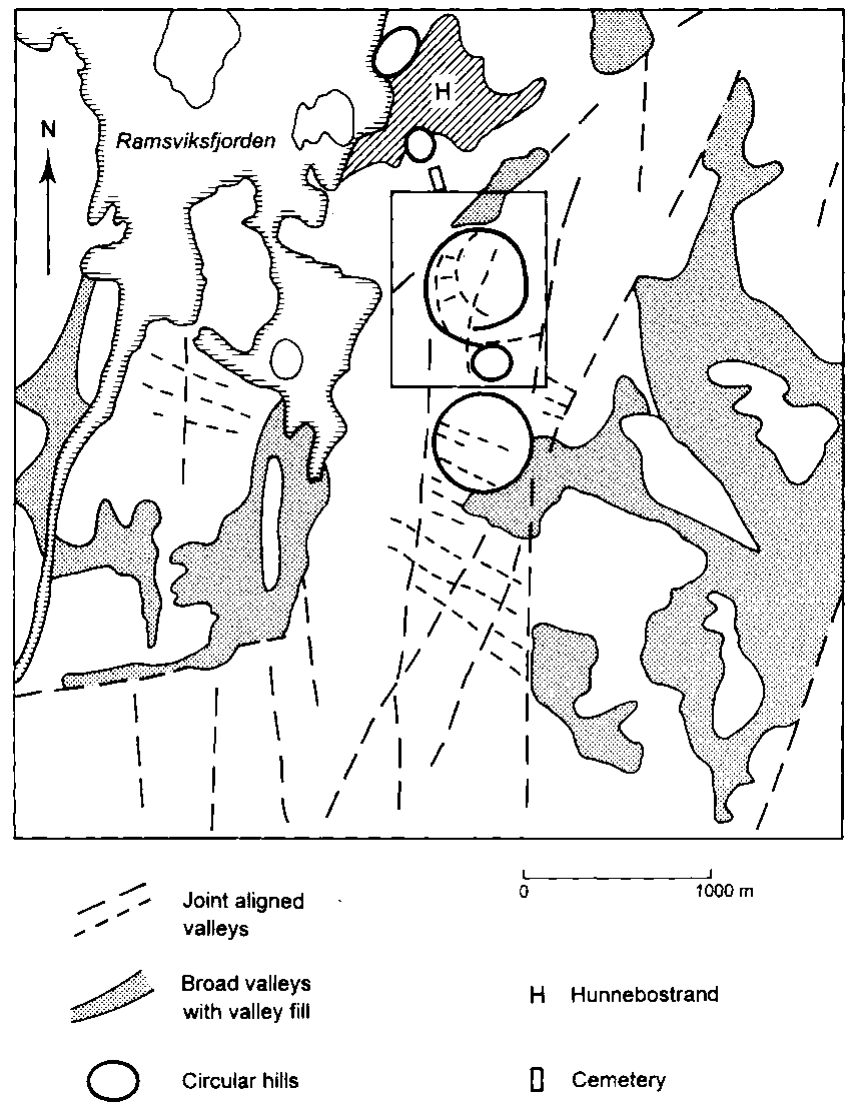

Fig. 2. Foint-aligned valleys and circular rock hills in the granitic region of Bohuslän at Hunnebostrand. Inset box refers to inset map in the upper right corner of Figure 3.

\section{METHODS}

Small- to medium-scale bedrock forms were mapped, described and classified either as glacial or non-glacial. The non-glacial forms were further subdivided according to process of formation. The glacial surfaces were used as a relative time reference for interpretation of the geomorphological evolution. The other forms were determined to be either older or younger than the glacial surfaces.

\section{Form-process considerations}

\section{Bedrock forms related to weathering processes}

In most rocks, deep weathering (that is sub-surface weathering) works preferentially along joints or other types of partings. In rocks such as granite, this effect is significant due to the marked contrast in permeability between fractured and intact rock blocks (Twidale, 1982; Twidale and Campbell, 1993). This favours the movement of meteoric water along such partings, which thus forms the initial loci of decomposition. Weathering will start at the original joint surface and the zone of decomposed rock will progressively grow laterally and parallel with this surface. As a consequence, straight joint-controlled bedrock surfaces, clefts and widely opened joints will appear after stripping of the weathering products. Fresh cores of the rock with rounded edges (tors) as well as residual boulders, once corestones in the weathered rock, will also be left after stripping.

The transition from fresh to friable weathered rock is often separated by a zone consisting of laminated masses of lessaltered rock, which extends conformably around boulders or runs parallel with joint surfaces (Twidale, 1982). The resulting spalls or flakes, produced by exfoliation, are known to develop by surface and sub-surface weathering. We have noted this type of weathering both on corestones within saprolites in southern Sweden (Lidmar-Bergstöm and others, 1997) and on glaciated surfaces in Bohuslän and other parts of Sweden. Differential weathering at a mineralogical scale will produce rough rock surfaces which also form in both subsurface and surface environments (Twidale and Bourne, 1976; LidmarBergström, 1989; Swantesson, 1989).

\section{Forms related to erosion by ice sheets and subglacial meltwater}

Glacial erosion in hard rock is a result of abrasion, plucking, subglacial water erosion and subglacial dissolution (Drewry, 1986). The most conclusive evidence of glacial abrasion is striae or grooves. Plucking is the effect of fracturing, loosening and evacuation of rock fragments by different subglacial processes (Drewry, 1986). This leads to the formation of freshly broken rock surfaces with sharp edges, and a jagged and sometimes stepped outline. Abrasion and plucking lead to the evolution of the classic roche moutonnées. However, the actual bedrock form produced is highly variable and dependent on rock structure (Ljungner, 1930; Rastas and Seppälä, 1981; Laitakari and Aro, 1985).

Subglacial meltwater erosion may erode the bedrock surface and produce a variety of forms at different scales. In the study area, most typical subglacial meltwater forms are potholes and variously shaped longitudinal furrows, cavettos and flutes with typically concave or trough-shaped cross-sections.

\section{Forms related to wave abrasion}

Some examples of vertical joints, exploited by shore processes during isostatic uplift, occur along the Swedish west coast (Sjöberg, 1986). These so-called tunnel caves have a form that resembles a wine glass turned upside-down. The caves can form in areas open to the sea, where concentrations of beach shingle occur. The position of the tunnel, the widened joint, is a function of its relation to sea level during a stage when the fetch and the availability of abrading material were optimal. The abraded tunnel walls are smoothly rounded or flared and notably well-polished. These wave-abraded surfaces are easy to distinguish from glacially abraded surfaces. It is, however, difficult to distinguish between marine abrasion and abrasion by subglacial meltwater, but the local conditions often clarify the situation. Still there is some uncertainty in this case.

\section{RESULTS}

The mapped area includes seven rock blocks and eight intervening clefts (Fig. 3). The two northernmost and centrally situated blocks exceed $65 \mathrm{~m}$ a.s.l. The block to the south of cleft (3) is 50-55 m a.s.l., and the two northernmost of the westerly blocks are 40-50 m a.s.l. The southwestern block only reaches $35 \mathrm{~m}$ a.s.l. The mapped features of clefts and summits are presented in Fig. 3 and divided into three groups: (1) structural and weathering forms; (2) glacial forms; and (3) boulders. Some comments on the vertical distribution of forms and other features not easily read from the map will follow.

\section{Glefts}

\section{Non-glacial features: joint-controlled clefts and weathering}

The clefts have vertical joint-controlled walls, which range in height from a few metres to about $15 \mathrm{~m}$. The floor at the 


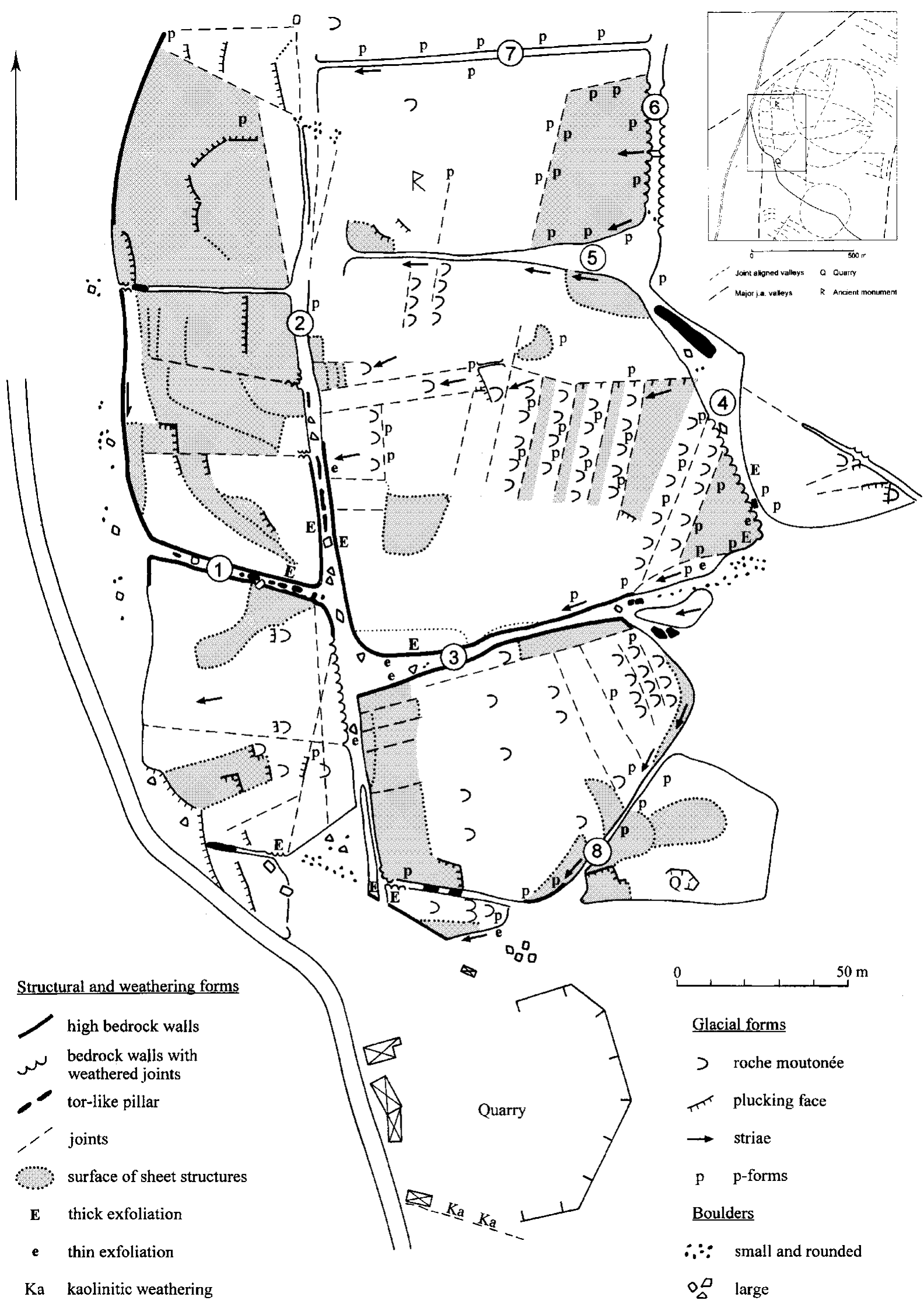

Fig. 3. The Hunnebo clefts mapped by Göran Lindberg, Karna Lidmar-Bergström, Fan Bergström and Mats Olvmo. Inset map: Bedrock structures mapped from air photos within and around the study area south of Hunnebostrand. The clefts are numbered (1)-(8).

mouth of cleft (1) is about $25 \mathrm{~m}$ a.s.l. The rock walls are parted by horizontal sheeting joints and, particularly in the inner part of cleft (1), are separated by many vertical joints resulting in the formation of rock blocks. Weathering occurs along the joints and has caused rounded edges on the blocks. Cleft (1) is occupied by tor-like pillars of granite, with rounded edges. The pillars increase in height in the inner part, where granite boulders are perched on each other, in situ (Fig. 4). Exfoliation sheets, 0.05-0.1 m thick occur along the northern wall, on the pillars and also on some of the boulders strewn on the floor. On the rock walls, as well as on the boulders, there is a typical rough surface caused by 


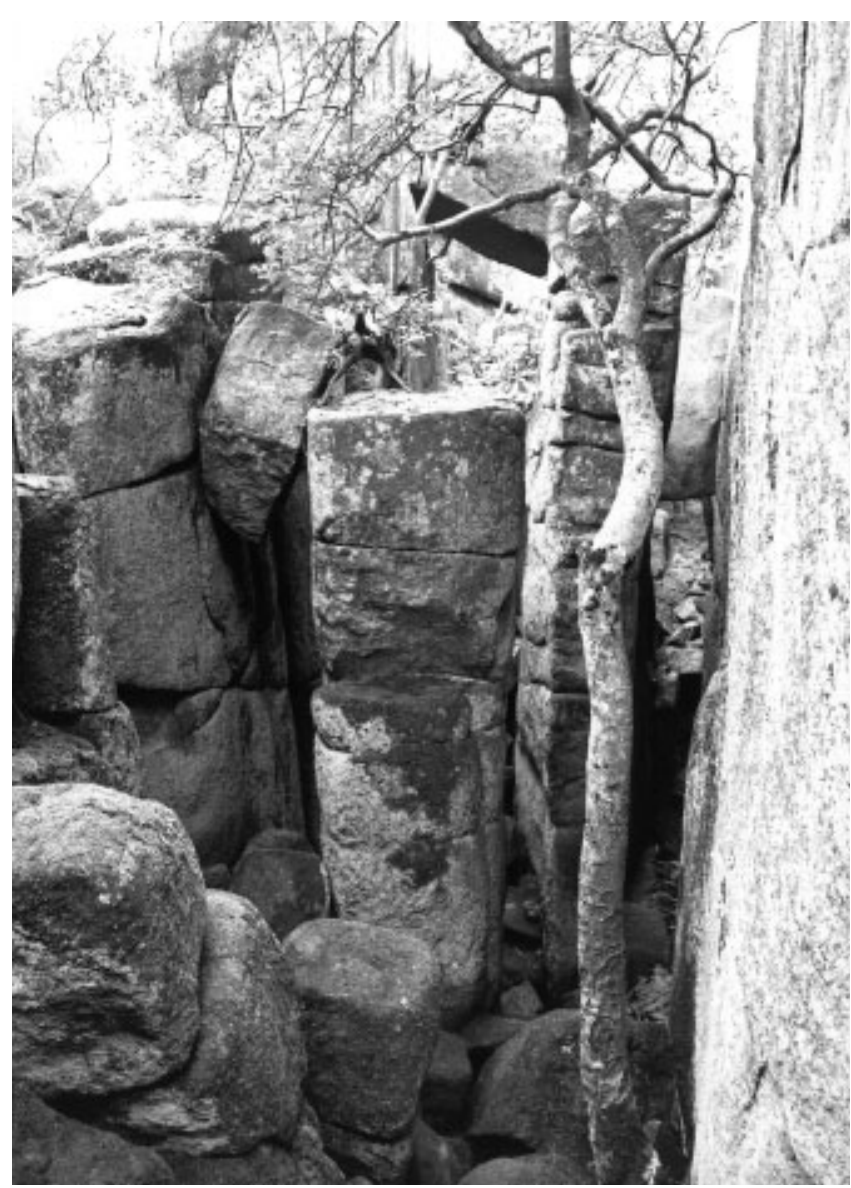

Fig. 4. Tor-like pillars, Hunnebo, the eastern part of cleft (1) (see Fig. 3 for location). View towards the west. The pillars in the centre are about 3 and $4 \mathrm{~m}$ high, respectively. Note also the boulders with rounded edges in the lower left corner. (Photo by M. Johansson).

differential mineral weathering. A $0.2-0.3 \mathrm{~m}$ wide vertical zone in the easternmost part of the cleft is weathered in situ to gruss. The weathering emanates from a central joint. There is also a high amount of fine angular quartz and alkali feldspar gravel on the cleft floor. These features are characteristic for most of the clefts. Cleft (3) is the deepest cleft. Torlike pillars are present only in the eastern part. Thick exfoliation occurs along the northern wall, and in the western end, large exfoliated blocks rest as boulders on the ground. Otherwise, this cleft is mainly devoid of boulders.

In most of the clefts, weathering has acted extensively along sheeting joints in the walls and well-rounded surfaces have formed between the joints. Good examples are exposed in clefts (4) and (6) (Fig. 5). As a result of this weathering, the edges of the sheeting structures have distinct convex profiles (cf. Fig. 7).

Evidence of kaolinitic deep weathering is documented in the abandoned quarry in the southernmost part of the area. Here, the granite is weathered to a soft and friable saprolite within about a $0.5 \mathrm{~m}$ wide vertical fracture zone (Fig. 3). The clay fraction consists of kaolinite and smectite, the same minerals as within the basal parts of Mesozoic saprolites in southern Sweden (Lidmar-Bergström and others, 1999).

\section{Effects of glacial erosion and erosion by subglacial meltwater}

In general, the cleft walls have no traces of glacial abrasion and are unaffected by glacial erosion. However, erosion by subglacial meltwater has exploited the weathered sheeting structures along the upper part of the steep wall facing

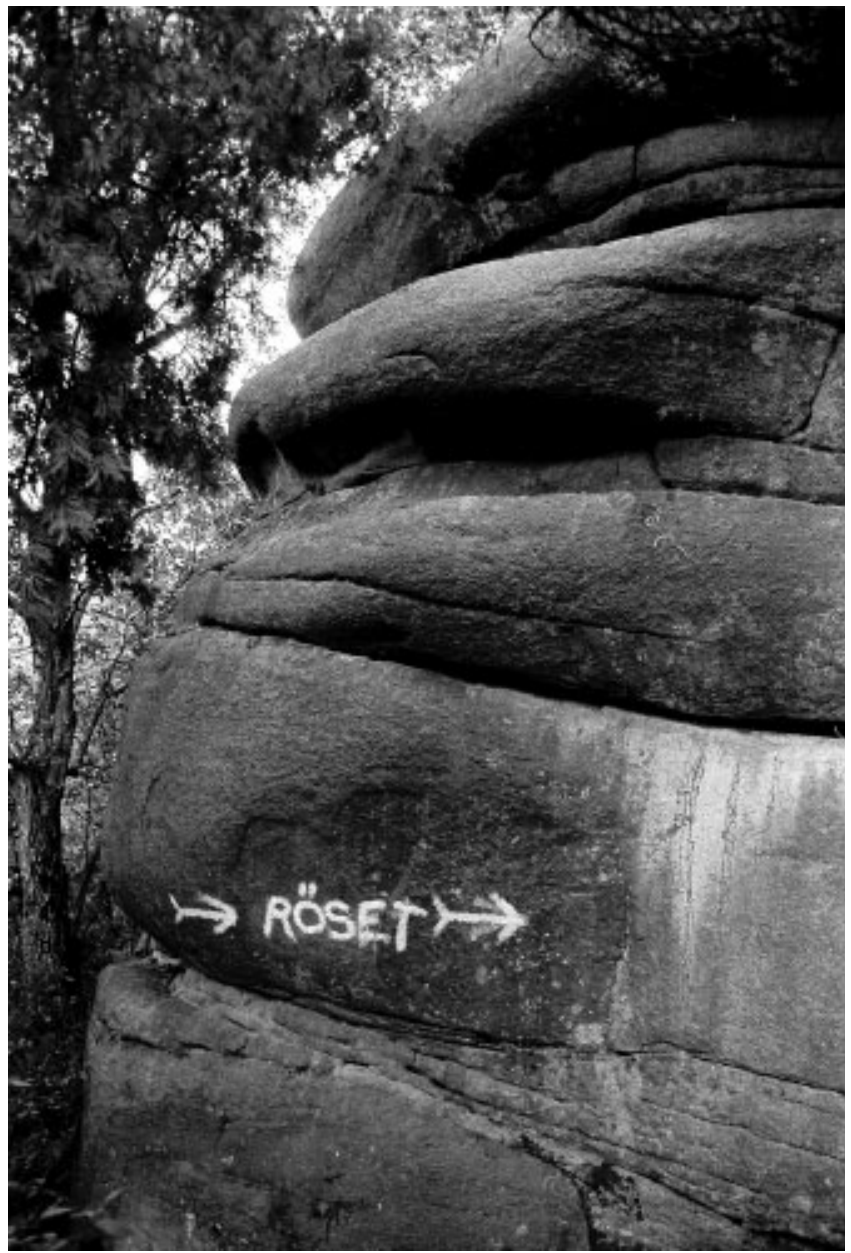

Fig. 5. Sheets of granite weathered to convex forms at the intersection between clefts (3) and (4) (Fig. 3). A thick exfoliated granite slab can be seen on the lowermost sheet structure. The exposed rock wall on the photo is approximately $4 \mathrm{~m}$ high. Photo towards west-southwest.

southwards at the eastern end of cleft (3). Furrows with concave cross profiles have been formed (Fig. 6). These forms are normally referred to as $p$ forms (Dahl, 1965; Benn and Evans, 1998), or sometimes $s$ forms (Kor and others, 1991). They have been incised into the original convex weathering forms (Fig. 7). This type of reshaping by subglacial meltwater is frequent and it demonstrates that the convex weathering forms predate the concave glacial forms. Such $p$ forms are common and welldeveloped along the upper parts of clefts (3), (5), (7) and (8), but are also developed to some extent along cleft (6).

\section{Marine abrasion of cleft walls}

The pillars in the centre of cleft (1) are polished on the sides exposed to the western (seaward) entrance, while east-facing surfaces are rough. The winding cleft (3) has slightly curved overhanging walls in the centre. Beach pebbles partly cover the floor and the lower parts of the rock walls are occasionally nicely polished. Marine abrasion may have contributed to the shape of the walls.

\section{Zonation of forms}

Observations of the vertical distribution of forms caused by weathering and by erosion of glaciofluvial meltwater can be summarized as follows (Fig. 7). Weathering features predominate in the lower part of the cleft walls, however some are remodelled by wave action. In the uppermost parts, the weathering forms have been remodelled by glacial erosion, 


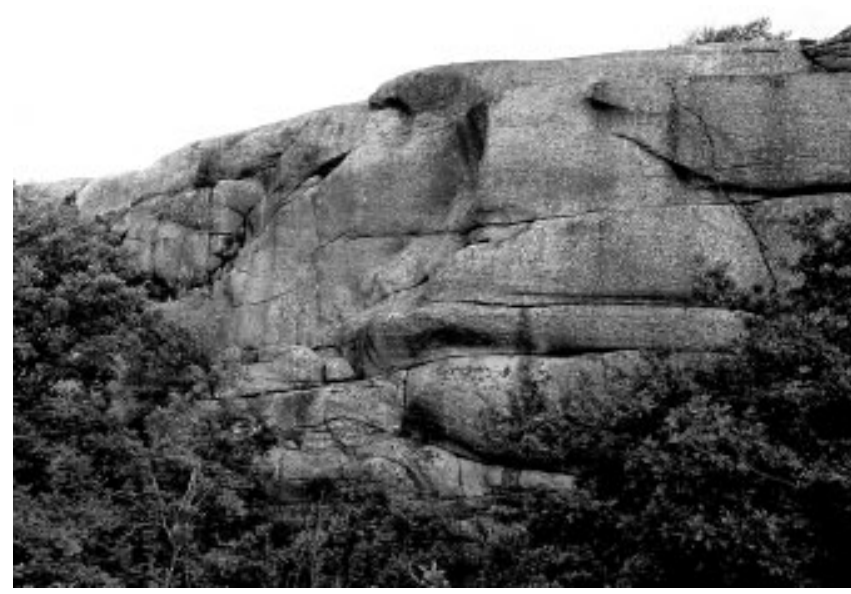

Fig. 6. Convex sheet ends truncated and reshaped to concave $\mathrm{p}$ forms on the northern upper wall in the easternmost part of cleft (3) (Fig. 3; cf. Fig. 5).

mainly by subglacial meltwater, and many weathering forms have been converted to $p$ forms.

\section{Forms outside the clefts}

The plateau-like summit

In contrast to the clefts, the plateau-like summit (between clefts (2), (7), (6), (4), and (8)) of the hill is highly affected by glacial abrasion. Roche moutonnées, indicating ice flow from the northeast, occur in abundance. The structural influence is prominent since the sheeting has a major influence both on the plateau form and on the stoss- and lee-side topography (cf. Ljungner, 1930). The sheeting joints dip gently away from the ice-flow direction. Steep and short stoss sides are developed on the outcropping edges of the sheet structures (Fig. 8). The lee sides are often conformable with gently dipping sheeting joints due to joint-controlled glacial plucking.

Selective erosion, by subglacial meltwater of the top surface, is shown by more or less continuous plastically sculptured furrows. The $p$ forms commonly follow structures running parallel to the ice-flow direction, but the systems are sometimes dislocated by cross joints.

The glacially eroded summit surface at Hunnebo is also

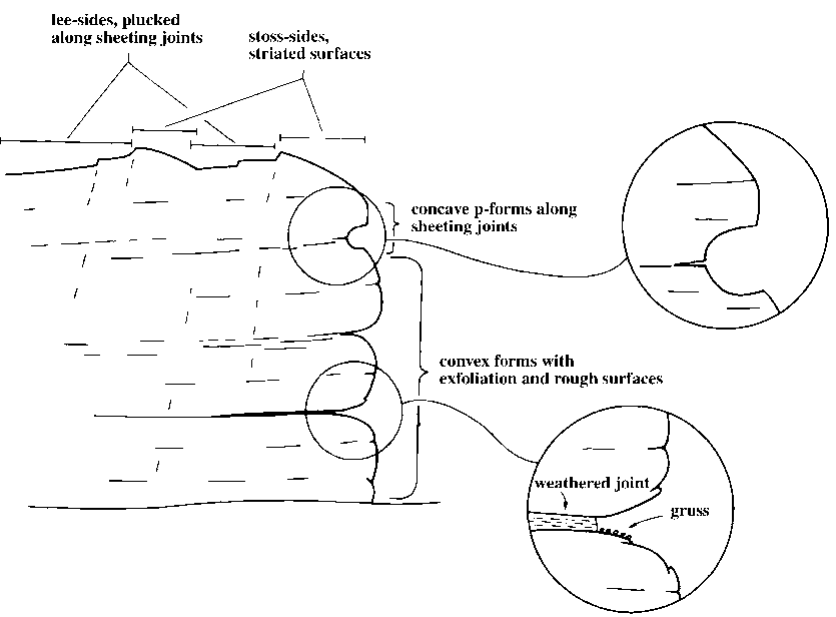

Fig. 7. Principal sketch of vertical zonation of forms within the clefts.

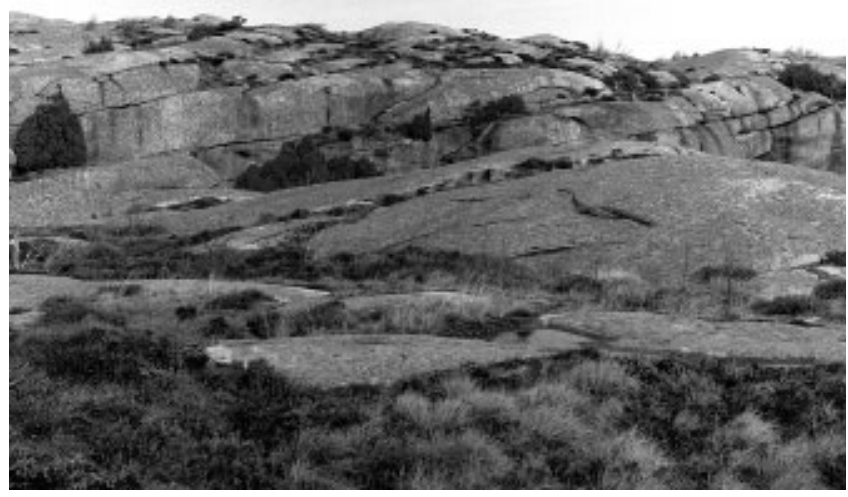

Fig. 8. Top surfaces of plateaux between clefts (3) and (8) (foreground) and (2)-(5) (background). Cleft (3) cuts through the centre. Note the influence of sheeting on the stoss-and lee-side topography. Steep stoss sides have normally developed on the outcropping edges of bedrock sheets, while plucking has occurred preferentially along southwest-dipping sheeting joints. Photo towards north.

characterized by different types of small-scale glacial forms. Striae are ubiquitous, but often partly remodelled and sometimes completely obliterated by postglacial weathering. Other small-scale features, such as friction cracks and chattermarks, are widely distributed, but are normally reshaped by postglacial weathering. Postglacial weathering has been most effective in small glacial troughs (Sichelwannen), where moisture retention has promoted weathering. The initial pits have often developed further by a thin flaking. It is, however, important to note that postglacial weathering has been incapable of significantly rounding glacially broken edges.

\section{The top surfaces of the low-rock compartments}

The surfaces of the westerly low-rock compartments (west of cleft (2)) follow the sheeting of the granite and are glacially plucked surfaces. The two compartments in the northwest are in the lee of ice from the northeast and no roche moutonnées have developed.

\section{The hill sides}

The northeastern part, outside the mapped area, is heavily glacially abraded and the sides are less steep. The steep western walls of the hill have slightly flared slopes, the origin of which are obscure. They are either weathering forms (cf. Twidale, 1982) or glacial forms developed by ice flow from the north, as these walls have preserved north-south striae.

\section{EVALUATION AND TIMING OF LAND-FORMING PROGESSES}

An evaluation of the importance of different processes for the bedrock forms in the study area is presented in Table 1 . The landforms of the granite are controlled by well-developed vertical and horizontal joint systems, just as in areas not affected by glaciations (Twidale, 1982; Twidale and Campbell, 1993; Twidale and others, 1996). 
Table 1. Relative importance of different processes

Lowerclefts Upperclefts Summits

$\begin{array}{lccc}\text { Sheeting } & + & + & +++ \\ \text { Vertical jointing } & +++ & +++ & + \\ \text { Deep weathering } & +++ & +++ & ? \\ \text { Preglacial stripping } & - & ? & ? \\ \text { Exfoliation, thick } & ++ & ++ & - \\ \text { Exfoliation, thin } & + & + & + \\ \text { Differential surface weathering } & + & + & + \\ \text { Glacial plucking } & - & - & ++ \\ \text { Glacial abrasion } & - & + & ++ \\ \text { Erosion by subglacial meltwater } & (+) & ++ & + \\ \text { Marine erosion } & (++) & - & -\end{array}$

\section{Origin of the clefts}

The forms of the clefts and the saprolite remnants suggest that weathering processes were important for their formation. The weathering forms are particularly well-preserved in clefts protected from glacial erosion and erosion by subglacial meltwater, particularly in those running northsouth. Weathering along joints is clearly older than the $p$ forms exploiting them.

A map of the clefts (incorrect concerning their width, length and orientation) was presented by Mahaney and Sjöberg (1993). They argued for a Pliocene age for etching of the clefts, referring to the dissolution of quartz grains. The preserved kaolinitic saprolite in the fracture in the quarry suggests that the original deep weathering responsible for the cleft formation is Mesozoic. As no remnants of cover rocks are preserved within Bohuslän and the area has experienced a (Late) Tertiary uplift (Lidmar-Bergström, 1996; cf. Japsen, 1998), it is probable that the Mesozoic cover was already gone in the Neogene. It is possible that the clefts have been affected by repeated events of etching, stripping and burial. Due to the occurrence of beach pebbles and wave-abraded surfaces, it is suggested that marine erosion is responsible for the latest stripping event in the lower parts of the clefts. Erosion by subglacial meltwater has mainly affected the upper parts of the clefts, except for cleft (3), where it might have influenced the whole cleft.

\section{Structural importance for glacial shaping and re- shaping of forms}

It is quite obvious that sub-horizontal sheeting governs the plateau-like top surfaces and has also strongly influenced the shape of the medium-scale glacial forms (cf. Ljungner, 1927, 1930). Reshaping of the upper parts of the clefts by subglacial meltwater led to the transformation of the convex edges of the rock sheets to concave $p$ forms along the preglacially weathered sheeting joints. Glacial plucking along sheeting joints has contributed to a stepped appearance of the west-facing slope. The lee-side compartments have been lowered about 20-30 $\mathrm{m}$ by glacial plucking, which gives the hill an asymmetrical form.

\section{Postglacial shaping}

Postglacial thick exfoliation occurs in positions sheltered from glacial erosion. The absence of thick exfoliation sheets on glacially abraded surfaces suggests that the present exfoliation results from reactivation of preglacially weathered cleft walls.
Postglacial differential weathering and thin exfoliation have affected all kinds of surfaces, both inside the clefts and on the summits, but their morphological effects are only marginal.

\section{THE GLACIAL IMPACT: A DISGUSSION}

The general forms of the landscape in Bohuslän and around Hunnebostrand, controlled by lithology and structures, are typical of etched terrains throughout the world (Twidale, 1982; Ollier, 1984; Thomas, 1994). The difference is that, compared to nonglaciated areas, little is left of the original saprolites. Compared to central and northeastern Skåne and southernmost Sweden, with many thick saprolite remnants, Bohuslän is almost stripped of its saprolites and remnants only occur within narrow fracture zones or clefts. The area gives the impression of a scoured glacial terrain.

How much fresh bedrock has the ice eroded? It is difficult to judge, but the direct abrasion is limited to decimetres or metres on the stoss sides and the main erosive effect has been achieved by plucking, which amounts to at least 20$30 \mathrm{~m}$ on the lee side. It is probable that whole sheets of bedrock have also been plucked from the high summits. The available relief in the Precambrian bedrock from the position of the sub-Cambrian peneplain can be estimated to be about $100 \mathrm{~m}$ (Lidmar-Bergström, 1988; fig. 3h). As the whole appearance of the landscape is of etch character, it is probable that part of this amount was denuded in preglacial times (Mesozoic and Late Tertiary) so we end up with the conclusion that some tens of metres may have been removed from the high summits by glacial erosion.

Glacial erosion has not obliterated the bedrock hills that are characteristic of an etch surface, but many hills are asymmetric due to glacial plucking. In protected positions, even non-glacial medium-scale weathering forms are preserved. The latest stripping event might be postglacial, caused by marine abrasion. Glacially formed features in the bedrock are of meso- and microscale and occur on hilltops and stoss sides. Glacial scouring does not mean a total obliterating of preglacial landscapes and residual hills are definitely not destroyed by glacial erosion, as is suggested by Selby (1982; p. 191). It is, however, only in areas with extensively preserved saprolites and limited glacial reshaping of forms that we can talk about weak glacial erosion.

\section{GONGLUSIONS}

It is important to establish the inherited character of a landscape before the impact of glacial erosion is evaluated. The granite forms in Bohuslän mainly exhibit the same basic shape as granites in nonglaciated areas, but with some very specific alterations. The most notable difference from nonglaciated terrain is the absence of the weathered mantle. Landscapes labelled "areally scoured glacial terrain" can, at least in some locations, also be described as totally stripped and slightly incised etch surfaces. This study has further emphasized the importance of detailed field mapping of bedrock surfaces and saprolite remnants for sorting out the processes involved in the ultimate shaping of the relief.

\section{REFERENGES}

Asklund, B. 1947. Svenska stenindustriområden I-II. Gatsten och kantsten. Sver. Geol. Unders., Ser. C 479, 3-187.

Benn, D. I. and D. J. A. Evans. 1998. Glaciers and glaciation. London, Arnold. 
Dahl, R. 1965. Plastically sculptured detail forms on rock surfaces in northern Nordland, Norway. Geogr. Ann., 47A(2), 83-140.

Drewry, D. 1986. Glacial geologic processes. London, Edward Arnold.

Elvhage, C. and K. Lidmar-Bergström. 1987. Some working hypotheses on the geomorphology of Sweden in the light of a new relief map. Geogr. Ann., 69A(2), 343-358.

Flodén, T. 1973. Notes on the bedrock of the eastern Skagerrak with remarks on the Pleistocene deposits. Stockholm Contri. Geol., 24(5), 79-102.

Japsen, P. 1998. Regional velocity-depth anomalies, North Sea chalk: a record of overpressure and Neogene uplift and erosion. AAPG Bull., 82(11), 2031-2074.

Johnsson, G. 1956. Glacialmorfologiska studier i södra Sverige. Med särskild hänsyn till glaciala riktningselement och periglaciala frostfenomen. Medd. Lunds Univ. Geogr. Inst. Avh. 30.

Kor, P. S. G., J. Shaw and D. R. Sharpe. 1991. Erosion of bedrock by subglacial meltwater, Georgian Bay, Ontario: a regional view. Can. 7. Earth Sci., 28(4), 623-642.

Kornfält, K. A. and J. Bergström. 1983. Beskrivning till berggrundskartan Karlshamn NV. Sver. Geol. Unders., Ser. Af 35.

Laitakari, I. and K. Aro. 1985. The effect of jointing on glacial bedrock hills in southern Finland. Fennia, 163(2), 369-371.

Lidmar-Bergström, K. 1982. Pre-Quaternary geomorphological evolution in southern Fennoscandia. Sver. Geol. Unders., Ser. C 785. (Medd. Lunds Univ. Geogr. Inst. Avh. 91.)

Lidmar-Bergström, K. 1988. Denudation surfaces of a shield area in south Sweden. Geogr. Ann., 70A(4), 337-350.

Lidmar-Bergström, K. 1989. Exhumed Cretaceous landforms in south Sweden. Z. Geomorphol., Supplementband 72, 21-40.

Lidmar-Bergström, K. 1995a. Preglacial landforms: an introduction. Geomorphology, 12(1), 1-2.

Lidmar-Bergström, K. 1995b. Relief and saprolites through time on the Baltic Shield. Geomorphology, 12(1), 45-61.

Lidmar-Bergström, K. 1996. Long term morphotectonic evolution in Sweden. Geomorphology, 16(1), 33-59.

Lidmar-Bergström, K. 1997. A long-term perspective on glacial erosion. Earth Surf. Processes Landforms, 22(3), 297-306.

Lidmar-Bergström, K. 1999. Uplift histories revealed by landforms of the Scandinavian domes. In Smith, B. J., W. B. Whalley and P. A. Warke, eds. Uplift, erosion and stability. London, Geological Society, 1-7. (Special Publication 162.)

Lidmar-Bergström, K., S. Olsson and M. Olvmo. 1997. Palaeosurfaces and related saprolites in southern Fennoscandia. InWiddowson, M., ed. Palaeosurfaces: recognition, reconstruction and interpretation. London, Geological Society, 95-123. (Special Publication 120.)
Lidmar-Bergström, K., S. Olsson and E. Roaldset. 1999. Relief features and palaeoweathering remnants in formerly glaciated Scandinavian basement areas. In Thiry, M., ed. Palaeoweathering, palaeosurfaces and related continental deposits. Oxford, International Association of Sedimentologists, 275-301. (Special Publication 27.)

Ljunger, E. 1927. Spaltentektonik und Morphologie der schwedischen Skagerrak-Küste I-II. Bull. Geol. Inst. Univ. Uppsala, 21, 1-254.

Ljunger, E. 1930. Spaltentektonik und Morphologie der schwedischen Skagerrak-Küste Teil III. Die Erosionsformen. Bull. Geol. Inst. Univ. Uppsala, 21, 255-478.

Lundqvist, J. 1994. The deglaciation. In Fredén, G., ed. Geology. Stockholm, Almqvist and Wiksell International, 124-135. (National Atlas of Sweden.)

Lundqvist, J. and B. Bygghammar. 1994. The Swedish Precambrian. In Fredén, C., ed. Geology. Stockholm, Almqvist and Wiksell International, 16-21. (National Atlas of Sweden.)

Mahaney, W. C. and R. Sjöberg. 1993. Scanning electron microscopy of quartz grains from two granite caves and a gorge system in Bohuslän, southwestern Sweden. Z. Geomorphol., 37(3), 337-348.

Menzies, J. 1996. Past glacial environments: sediments, forms and techniques. Vol. 2. Glacial environments. Oxford, etc., Butterworth-Heinemann.

Ollier, C. D. 1984. Weathering. Second edition. London, etc., Longman.

Rastas, J. and M. Seppälä. 1981. Rock jointing and abrasion forms on roches moutonnées, SW Finland. Ann. Glaciol., 2, 159-163.

Samuelsson, L. 1975. Palaeozoic fissure fillings and tectonism of the Göteborg area, SW Sweden. Sver. Geol. Unders., Ser. C 711.

Selby, M. J. 1982. Hillslope materials and processes. Oxford, Oxford University Press.

Sjöberg, R. 1986. Tunnelgrottor $i$ Norden: geomorfologiska studier. Umeå, Umeå Universitet. Geografiska Institutionen. (GERUM Naturgeografi 3.)

Sugden, D. E. 1978. Glacial erosion by the Laurentide ice sheet. F. Glaciol., 20(83), 367-391.

Sugden, D. E. and B. S. John. 1976. Glaciers and landscape; a geomorphological approach. London, Edward Arnold.

Swantesson, J. O. H. 1989. Weathering phenomena in a cool temperate climate. (Ph.D. thesis, University of Göteborg.) (GUNI Rapport 28.)

Thomas, M. F. 1994. Geomorphology in the tropics. A study of weathering and denudation in low latitudes. Chichester, Wiley.

Twidale, C. R. 1982. Granite landforms. Amsterdam, Elsevier.

Twidale, C. R. and J. A. Bourne, 1976. Origin and significance of pitting in granitic rocks. Z. Geomorphol., 20(4), 405-416.

Twidale, C. R. and E. M. Campbell. 1993. Fractures: a double edged sword. A note on fracture density and its importance. Z. Geomorphol., 37 (4), 459-475.

Twidale, C. R., J. R. Vidal Romani, E. M. Campbell and J. D. Centeno. 1996. Sheet fractures response to erosional offloading or tectonic stress. Z. Geomorphol., Supplementband 106, 1-24. 